https://doi.org/10.38129/Ann.Yur.Ist.2020.4.2.27

УДК 340.130.3: 321.17(321.011.1)

\title{
ПРАВЛЕНИЕ КОРОЛЕВЫ АМАЛАСУНТЫ В ИТАЛИИ (526-535 ГГ.): ИСТОРИКО-ЮРИДИЧЕСКАЯ ХАРАКТЕРИСТИКА
}

\author{
ВИКТОР МЕЛЬНИК (Киев, Украина) *
}

Остготский вождь Теодорих Великий правил Италией в качестве наместника восточноримских (византийских) императоров с 493 по 526 гг. Его правление привело к созданию мощного внешнеполитического союза, который в 519 г. включал не только Италию с прилегающими территориями Паннонии, Реции, Норика, Далмации, Прованса, но и всю Испанию, Северную Африку, Лионскую Бургундию, Тюрингию, Алеманнию, северогерманскую Саксонию. Соответственно, о самом Теодорихе Великом из рода Амалов, обладавшем имперскими титулами магистра, консула, патриция, часто говорят как о полноценном «наместнике провинций бывшей Западной Римской империи»1.

Перед своей смертью 30 августа 526 г., Теодорих Великий последний раз созвал совет военачальников. Понимая опасность любых антиимперских действий для родовой власти Амалов, Теодорих лично провозгласил королем собственного внука Аталариха и приказал вождям: «чтобы они охраняли и берегли короля, Возлюбили сенат и римский народ, а императора восточного - храня всегда мир с ним и его благосклонность - почитали вторым после Бога»². Теодорих позаботился, дабы слова его, через послов, дошли до ушей императора Юстина I.

Последним предсмертным решением Теодориха стало назначение собственной дочери Амаласунты (матери Аталариха) на пост официальной правительницы Италии вплоть до обретения Аталарихом совершеннолетияз Таким образом, как только король Теодорих умер, Амаласунта немедленно

${ }^{1}$ Мельник В. М. Смена эпох: очерк формирования римско-византийской доктрины международного права (III-VI века). Аннали юридичної історії. 2018. Т. 2. № 1-2. С. $96-$ 98.

2 Iord. Get., 304.

${ }^{3}$ О переходе власти к Амаласунте: Procop. BG, I.2.3; Iord. Get., 305; Iord. Rom., 367. Иордан также говорит о моментальном потеплении отношений между Амаласунтой и Юстином I. 
объявила себя наместницей византийского императора в Италии. В дальнейшем, как отмечает итальянский хронист Кассиодор, восьмилетнее правление Амаласунты (как регент 8 526-534 г2. и как королева в 534-535 г2.), стало демонстрацией полного подчинения рода Амалов высшей власти Константинополя и зависимости остготских королей от императорской воли

Малолетний и болезненный Аталарих Амал, де-юре, правил остготской Италией, Далмацией, Сицилией, Рецией, Нориком и Провансом вплоть до своей естественной смерти в 534 г. В 526 г. ему было всего лишь около десяти лет. Амаласунте к тому времени исполнилось двадцать восемь. Эта женщина получила римское образование высшего класса, превосходно знала греческий и латинский языки, владела навыками юридической грамотности и могла составлять деловые документы. Современник событий Прокопий утверждает, что Амаласунта «сочетала необычайную красоту и пленительную женственность с умом, энергией и решительностью зрелого мужчины» 5 .

Источник «Variae» Кассиодора посвящает Амаласунте много внимания, так как Кассиодор во времена её правления занял могущественное и влиятельное положение при дворе. Фактически, Кассиодор являлся вторым человеком в остготских владениях - итальянским канцлером, главным придворным писарем и руководителем королевской канцелярий. Важно, что и Кассиодор, и Прокопий, и Иордан единодушно подчеркивали «римский характер» Амаласунты, её склонности к римской культуре и образу мышления.

Прокопий, в частности, пишет: «Пока она стояла во главе управления, ни один римлянин не был подвергнут ни телесному наказанию, ни конфискации имущества; она не только не разрешала готам поступать несправедливо по отношению к римлянам, но даже вернула детям сенаторов Симмаха и Боэция имущество, конфискованное у их отцов» ${ }^{7}$. Сразу же, после восшествия малолетнего Аталариха на остготский королевский престол, регентша Амаласунта издала от имени сына Манифест, согласно которому, римляне и остготы провозглашались равными друг другу ${ }^{8}$.

${ }^{4}$ Cass. Var., VIII.1.

${ }^{5}$ Цит. по: Удальцова 3. В. Италия и Византия в VI веке. М.: АН СССР, 1959. - с. 237. Первоисточник: Procop. Н. а., XVI.1.

6 Ле Гофф Жак. Рождение Европы. Серия «Становление Европы». Пер. с фр. А.И. Поповой. Предисл. А.О. Чубарьяна. СПб: «Александрия», 2014. - с. 34-35.

7 Procop. BG., I.2.4-5.

8 Skibiński Tomasz. Gothorum Romanorumque consensus. Jedność Gotów i Rzymian w działalności politycznej Amalasunty. Vox Patrum. 2016. T. 66. No 36. s. 235-249. 
Нововведённый принцип равенства варваров и римлян исходил из природы права foedus, согласно которому варварские племена поступали в прямое подчинение высшей императорской власти ${ }^{9}$. И пришлые варвары, и коренные римляне, в течение V в. и первой четверти VI в., составляли важную налоговую базу для официального Константинополя ${ }^{10}$. Вот почему император Юстин I (518-527) поддержал первые политико-юридические шаги амбициозной регентши.

Форма общения между королевской администрацией и народом Италии, избранная Амаласунтой, давала свои плоды. Первые восемь лет после смерти Теодориха Великого стали временем экономической стабильности и социального равновесия в итальянском обществе. В дальнейших манифестах Аmaлариха, Амаласунта предоставляла экстраординарные знаки внимания городскому Римскому сенату и называла его традиционным и главным местом принятия политических решений 11 . Регентша Амаласунта пошла также навстречу Папской Архиепископии. Папа Римский провозглашался судебной инстанцией, к которой мог обратиться любой подданный-католик, живущий во владениях Аталариха. Кассиодор отдельно писал: «безопасность народа приносит славу римскому епископу, а его надзору как духовного владыки подлежит и духовная и телесная жизнь всех верующих»12.

Впрочем, внутриполитическое равновесие и примирение между отдельными группами влияния в Италии (королевская канцелярия в Равенне, папский дворец в Риме, советы военных старейшин в Вероне и Милане, патрицианская аристократия в Неаполе и на Сицилии ${ }^{13}$ ) сопровождалось паралельной деградацией внешней политики. Первым делом, речь идёт о сложной системе взаимоотношений между Равенной и варварскими племенами на окраинах Аталариховой вотчины ${ }^{14}$.

${ }^{9}$ Cellurale Mariateresa. Romani y Gothi en Italia. La comunión de derecho en la república unida de Justiniano. Revista de Derecho Privado. 2011, n. 21. pp. 21-22.

10 Amory Patrick. People and identity in Ostrogothic Italy, 489-554. Cambridge: Cambridge University Press, 1997. 548 p.

11 Cass. Var., VIII.2, 10, 11, 14, 15, 17 etc.

12 Цит. по: Удальцова 3. В. Там же. - с. 239. Сверено с первоисточником: Cass. Var., VIII.24 et XI.2.4.

13 Cellurale Mariateresa. Romani y Gothi en Italia. La comunión de derecho en la república unida de Justiniano. Revista de Derecho Privado. 2011, n. 21. pp. 21-40.

14 Мельник В. М. Смена эпох: очерк формирования римско-византийской доктрины международного права (III-VI века). Аннали юридичної історії. 2018. Т. 2. № 1-2. С. 100101. 
О расколе политического объединения варварских королевств Европы и Африки, сгруппировавшегося вокруг династии Амалов, с таким трудом созданного Теодорихом Великим, свидетельствуют «волнения», случившиеся в Далмации и в Южной Галлии. В частности, бросается $b$ глаза mот фракт, что маниоресты, указы и постановления времён регентства Амаласунты больше не обрашзаются к народу вестготской Испании 15 . Однако, слова о Южной Галлии всё еще присутствуют ${ }^{16}$.

В одном из манифестов, Амаласунта говорит, что все восставшие будут осыпаны королевскими милостями, если прекратят протесты. Она также демонстрировала желание облегчить налоговые тяготы для латиноязычных граждан ${ }^{17}$. Был издан специальный рескрипт для южноитальянского региона Бруттия, в котором регент поощряла «природную добычу золота»: «Для чего лежать без обработки тому, что может стать имущцеством, добытым честным путем: искать золота посредством войны - дурно; плавать по морям из-за него опасно; получать обманом - нечестиво; добывать же у самой природы - справедливо»18.

Пока легаты Восточной Римской империи заключали соглашения (526 г.) с африканскими вандало-аланами и лионскими бургундами, Амаласунта подготовила и отправила собственное посольство в Константинополь. В 527 г. эта группа итальянских послов прибыла во «вселенскую столицу» с «прошением мира».

Что же подразумевают византийские летописцы под словосочетанием «прошение мира», говоря о дипломатическом шаге остготской правительницы?

Во-первых, отметим, что посольская миссия остготов к Юстину была отправлена в мирное время. Речи о «прекращении боевых действий» не шло. Смысл посольства состоял в следующем: дочь Теодориха Амаласунта просила восточноримского императора признать её сына Аталариха законным королем остготов и наместником Италии, а её саму регентом короля. Итальянские послы называли себя слугами и рабами императора, напоминали Юстину об усыновлении им готского военачальника Евтариха, чьим родным сыном

\footnotetext{
15 В частности, см.: Skibiński Tomasz. Gothorum Romanorumque consensus. Jedność Gotów i Rzymian w działalności politycznej Amalasunty. Vox Patrum. 2016. T. 66. No 36. s. 235249.

16 Cass. Var., VIII.3-5 et 7.

17 Jamróz W. Amalasunta - uczona królowa gotów. Meander. 1981. Vol. 36. Zeszyt 7. s. 367370.

18 Cass. Var., IX.3.5.
} 
являлся король Аталарих. Легаты из Равенны сказали императору: «Не чужой человек, а твой близкий родственник просит у тебя мира»19.

Во-вторых, заметим, что под «прошением мира», послами имелась в виду также гипотетическая возможность военного вмешательства Византии в итальянские дела из-за непризнания Аталариха полноправным наместником Италии (в том числе, посредством использования племенных союзов бургундов и вандалов, признанных Юстином независимыми от власти итальянских наместников по договору 526 г.) $)^{20}$.

В ответ на посольское прошение Амаласунты, император Юстин I (518-527) официально признал Аталариха и Амаласунту правителями Италии, Сииилии, Далмации, Прованса, Норика, Реции и Паннонии, что стало последним его важным прижизненным политическим решением... Уже летом 527 г. на восточноримский престол взошёл племянник Юстина Юстиниан Великий (527-565). Отметим, что современники сообщали о наличии личных любовных симпатий между Амаласунтой и Юстинианом, что, конечно же, являлось мощной поддержкой для сторонников королевы в борьбе с оппозиционной остготской знатью.

Впрочем, пока Амаласунта занималась налаживанием политических отношений с императором Юстинианом, многие остготы выказывали своё открытое недовольство провизантийским внешнеполитическим курсом. Вопервых, военачальники Тулуин и Теодат подстрекали остготов к неприятию «женской власти»21. Во-вторых, важным элементом подстрекательства служил Договор Юстина с вандалами и бургундами от 526 г., подведший черту под военнополитическим доминированием остготов в бассейне Западного Средиземноморья. Многие готские военачальники считали составление такого договора «предательством со стороны Римской империи». В-третьих, остготы препятствовали назначению римлянина Либерия (общей креатуры

19 Cass. Var., VIII.1-4.

${ }^{20}$ Cм.: Heydemann Gerda. Chapter 1: The Ostrogothic Kingdom - Ideologies and Transitions. A Companion to Ostrogothic Italy. Ed. by Jonathan Arnold, Kristina Sessa, Shane Bjornlie. Leiden: Brill, 2016. pp. 17-46; Bjornlie M. Shane. Politics and Tradition between Rome, Ravenna and Constantinople: A Study of Cassiodorus and the Variae, 527-554. Cambridge, 2013. 370 pp.; Cellurale Mariateresa. Romani y Gothi en Italia. La comunión de derecho en la república unida de Justiniano. Revista de Derecho Privado. 2011, n. 21. pp. 21-40.

${ }^{21}$ La Rocca Cristina Maria. Consors regni: a problem of gender? The consortium between Amalasuntha and Theodahad in 534. Gender and historiography. Studies in the earlier middle ages in honour of Pauline Stafford. Eds. Janet L. Nelson, Susan Reynolds and Susan M. Johns. London: Institute of Historical Research, 2012. pp. 127-130. 
Амаласунты и Юстиниана) высшим военным командиром Италии (магистром милитум). В дальнейшем, Амаласунта все же назначила на высшие военные остготские посты других римских сенаторов - Киприана и Опилиопа.

Не обошлось во внешней политике и без прямых военных столкновений с соседями. К примеру, Э. Штейн в своей «Истории Византийской империи» пишет, что византийцы решили ограничить потенциальную власть остготов в дунайском регионе и организовали вторжение в юго-западную Паннонию армии федератов из германского племени гепидов 22. В любом случае, гепиды были полностью разгромлены около Сирмия (современной Митровицы Сремской). Кажется вполне реальным предположение, что Амаласунта договорилась с Юстинианом о таком вторжении, в результате чего остготские военачальники должны были потерпеть поражение и, как следствие, потерять авторитет, если не жизнь. Все получилось ровно наоборот. Военная остготская знать восторжествовала, продолжая распускать слухи о «предательстве женщины». Прокопий писал об этом: «варвары уже открыто восставали против нее и без стеснения требовали, чтобы она, женщина, сложила царскую власть» 23 .

Сильно накалившиеся отношения остготов с вандалами и франками тоже давали о себе знать. Против Амаласунты составился серьезный заговор. Военная знать требовала прекращения классического римского образования Аталариха. В обществе абсолютно серьёзно дискутировался вопрос о том, надо ли остготскому королю уметь читать и писать собственной рукой, знать древние римские предания и летописи. В итоге, Амаласунта вынуждена была уступить напору генералов-заговорщиков и передать Аталариха на воспитание военным вождям. Видимо, это действие стало главной ошибкой Амаласунты и началом её политического конца.

Пока остготские дружинники сражались в паннонийском регионе с дикими гепидами, а Амаласунта пыталась сохранить материнский контроль над Аталарихом, вандалы под руководством нового рекса Гелимера совершили ряд жестоких набегов на южное и восточное побережье Сицилии. Отдельные пиратские отряды высаживались в южноитальянских регионах Апулия и Калабрия, где занимались разбойными нападениями на зажиточных римлян, порабощали крестьян и жгли католические церкви.

22 Stein Ernest. Histoire du Bas-Empire. Tome II, De la Disparition de L'empire D'occident a la Mort de Justinien (476-565). Bruges: Desclée De Brouwer. 1949. p. 329.

23 Procop. BG., I.2.20-21. 
Нападения гепидов и вандалов символизировали вступление остготского племени в новую историческую стадию. Настало время расплаты за дерзкую и жестокую политику Теодориха Великого, базировавшуюся на праве сuль²4.

Заметим, что вопрос о престолонаследии был настолько важен для варварских народов и их королей именно из-за доминировавшего в те годы права силы. Проигравший терял не только регалии или посты, но и социальное положение, честь и, конечно же, жизнь... Вспомним поучительный пример конфедеративного гуннского объединения Аттилы (годы существования: 434453 гг.). Оно распалось тотчас же, как только сыновья полководца не сумели договориться о мирном разделе властных полномочий (454-455 гг.). Соответственно, гуннское объединение ослабло, а единый центр доходов трансформировался в многочисленные локальные центры принятия решений и аккумуляции прибыли. То, что действительно объединяло европейские варварские племена вокруг гуннов, выражалось в гуннской военной мощи и успехах. Власть кочевников держалась на банальном страхе. Когда все это исчезло вместе с полководческим талантом Аттилы, то в вихре восточноевропейской истории бееследно пропало и само племя гуннов ${ }^{25}$.

Подобным Аттиле образом обстояли дела Теодориха Великого, чьё политическое объединение остготов, без сомнения, не уступало гуннскому союзу Аттилы по культурно-цивилизационному масштабу, хотя военная сила Теодориха и уровень централизованного управления зависимыми регионами выражались намного слабее. Впрочем, как оказалось в 526-534 гг., вся политическая структура остготской власти также держалась исключительно на личностных характеристиках одного человека - Теодориха ${ }^{26}$.

Ещё перед его смертью проявились симптомы дальнейшего распада остготского политического союза. В 524-526 гг. бургунды и вандалы самовольно

24 О принципиальных характеристиках права силы в раннем средневековье см.: Heydemann Gerda. Chapter 1: The Ostrogothic Kingdom - Ideologies and Transitions. A Companion to Ostrogothic Italy. Ed. by Jonathan Arnold, Kristina Sessa, Shane Bjornlie. Leiden: Brill, 2016. pp. 17-46; Gasparri Stefano, La Rocca Cristina Maria. Tempi barbarici. L'Europa occidentale tra antichità e medioevo (300-900). Roma: Carocci, 2012. 357 p.; Gasparri Stefano. Prima delle nazioni. Popoli, etnie e regni fra antichità e Medioevo. Roma: Carocci, 1997. 244 p.

${ }_{25}$ Мельник В. М. Смена эпох: очерк формирования римско-византийской доктрины международного права (III-VI века). Аннали юридичної історії. 2018. Т. 2. № 1-2. С. $91-$ 92.

26 Ле Гоффр Жак. Рождение Европы. Серия «Становление Европы». Пер. с фр. А.И. Поповой. Предисл. А.О. Чубарьяна. СПб: «Александрия», 2014. С. 51. 
вышли из подчинения Равенне, а испанские вестготы занялись своими внутренними делами, отказываясь платить дань Италии, самостоятельно обмениваясь посольствами с официальным Константинополем. Уже тогда можно было спрогнозировать: политические структуры Амалов ожидает такой же крах, как и гуннов. Действительно, в 526-527 гг. внешнеполитический союз Теодориха распался. Вестготия, Бургундия, Вандало-Алания пошли своим путём. Италия оказалась зажата между потенциально опасными противниками. На этот тяжелый процесс наслаивались пессимистические предрассудки раннего средневековья, отсутствие практики женского управления в публичном пространстве остготского общества. Ещё Кассиодор отмечал, что Амаласунта, при всем своем желании, не могла разговаривать с остготской военной знатью «на одном языке». В силу распада могущественного союза, созданного её родным отцом, с персоной Амаласунты широкие массы населения начали ассоциировать все политические и военные несчастья, постигшие остготское племя. Амаласунта использовала право силы в меньшей мере, чем её отец, и, как следствие, проигрывала на всех фронтах противостояния за политическую власть 27.

Итак, в 531-532 гг. внутренняя политическая борьба среди остготов достигла пика. Амаласунта обратилась к Юстиниану с просьбой спасти её вместе с остготской королевской казной28. 40 тысяч либр золота, по оценкам Пропокопия, были доставлены в византийский порт Диррахий (современный албанский город Дуррес). Император Юстиниан принял решение, что сама Амаласунта будет оставаться в Италии до последнего момента и в случае прямой угрозы её жизни, византийский военно-морской флот эвакуирует правительницу. Впрочем, этого Юстиниану делать не понадобилось. Амаласунта, используя наёмных убийц, сумела физически уничтожить трёх вождей оппозиции. Противники испытали шок и Амаласунта упрочила политическое положение династии Амалов. Сокровища остготов доставили из Диррахия обратно в Равенну 29.

Эту политическую победу Амаласунта укрепила назначением римлянина Кассиодора префектом претория Италии. На 534 г., с позволения Юстиниана Великого, впервые за последние три года был назначен консул от западных провинций Римской империи. Им стал знатный патриций и член римского

27 Sirago Vito A. Amalasunta la regina. Milano: Saggi Storici, 1999. 128 p.

28 Procop. BG., I.2.25-26.

29 Procop. BG., I.2.29. 
сената из древнего рода Дециев. В свою очередь, префект претория Галлии Либерий получил почетный титул patricius praesentalis ${ }^{30}$.

Амаласунта восстановила все преференции и денежное государственное содержание для сословия учителей. Особое внимание Амаласунта уделила риторам и грамматикам Рима31. Правительница обязала римский городской сенат предпринять все возможные шаги для восстановления системы классического обучения, функционировавшей во времена правления западных императоров. Каждую учительскую кандидатуру сенат должен был рассматривать и утверждать в режиме открытого голосования ${ }^{32}$.

В 533 г. Амаласунта издала от имени Аталариха указ о мероприятиях по борьбе с коррупцией внутри ортодоксальной (католической) церкви. Все постановления, подготовленные Амаласунтой от имени Аталариха, были кодифицированы (собраны и обобщены) в т. н. Эдикте Amaлариха (533 г.). Его основной идеей необходимо считать провозглашение неприкасаемости королевских привилегий дома Амалов и обеспечение юридической преемственности в законодательной деятельности правительства Амаласунты относительно предыдущего кодификационного акта - Эдикта Теодориха Великого (512 г.). Кассиодор подчеркивает, что Эдикт Аталариха акцентировал внимание на сохранении и даже расширении имущественных прав римского населения 33 . В целях борьбы с остготскими оппозиционерами, Эдикт устанавливал суровые наказания для тех германцев, которые посмеют обидеть римлянина или применить насилие по отношению к латиноязычным гражданам ${ }^{34}$.

В 533-534 гг. произошло важнейшее в истории Европы событие. Армия византийского полководца Велизария, по приказу Юстиниана, совершила победоносный поход в Северную Африку. Вандало-аланское войско потерпело сокрушительное поражение, их короля пленили и заковали в кандалы, а все территории на запад от Карфагена признали высшую власть императора Восточной Римской империи.

Заметим, что уничтожение восточноримской армией Карфагенского

\footnotetext{
30 Stein E. Ibid. - t. II. - p. 334.

31 Jamróz W. Amalasunta - uczona królowa gotów. Meander. 1981. Vol. 36. Zeszyt 7. s. 367377.

32 Cass. Var., IX.21.2 et 5.

33 Cass. Var., IX.18-19.

34 Bjornlie M. Shane. Politics and Tradition between Rome, Ravenna and Constantinople: A Study of Cassiodorus and the Variae, 527-554. Cambridge, 2013. 370 pp.
} 
королевства в 533-534 гг. не стало для остготов громом среди ясного неба. Известно, что Амаласунта оказала значительную материально-техническую и военную помощь флоту и сухопутным силам императорского полководца Велизария.

Наступление византийских войск в Северную Африку началось с наспех организованной военной базы на Сицилии. Амаласунта тогда открыто выступила против вандало-аланского короля Гелимера (530-534) организатора пиратских набегов на остготские провинции Сицилию, Апулию и Калабрию. Это вновь позволило внутренним противникам дестабилизировать общую социальную ситуацию в Северной Италии. Готы начали негодовать по поводу «сдачи братской Северной Африки» и утверждать, что византийцы лишь готовят плацдарм для нападения на Италию, в то время как регентша Амаласунта помогает Юстиниану во всех его «преступлениях». Правительница, в свою очередь, напомнила жителям Италии, что они являются подданными византийского императора, а вандалы, в самый ответственный период для остготской Италии (526-527 гг.), сами пошли на сделку с Константинополем и откололись от внешнеполитического объединения Теодориха Великого.

Противники Амаласунты пытались разжечь конфликт с Константинополем, чтобы показать несостоятельность и бездарность её правления. Неапольский комит (военный командир готов) Улиарий собирал под свои знамена дезертиров из войск Велизария, а сицилийская группа остготов предприняла несколько агрессивных вылазок против островных территорий Средиземноморья, которые де-юре должны были перейти под власть администрации Велизария. Оппозиционеры хотели создать в константинопольском дворце ощущение ненадежности регентши, отсутствия в её руках реальных рычагов власти и влияния на поведение племенных вождей и комитов, в результате чего император вполне мог её сместить. Кроме того, остготские вожди тайно связались с женой Юстиниана императрицей Феодорой и попытались убедить её, что молодая правительница хочет развести её с императором и женить на себе 35 . Эту информацию, как и многие другие имперские «слухи и сплетни», сообщает летописец Прокопий в занимательной «Тайной истории». Он даже утверждает, что императрица Феодора (всего лишь год спустя) принимала деятельное участие в ликвидации Амаласунты. Понятно, что историографическая и, тем более, фактологическая репутация источника «Тайная история» оставляет желать лучшего и указанная

\footnotetext{
35 Procop. H. a., XVI.1.4-5.
} 
информация вполне может являться ложной. Однако канва такой полуправды Прокопия ясно свидетельствует о трудном политическом положении Амаласунты. В 534 г. оно представлялось современникам безвыходным. С одной стороны, её дружба с Юстинианом вызывала недовольство остготской знати, боявшейся полной ликвидации собственных привилегий новыми константинопольскими указами и чиновниками. С другой стороны, Амаласунта принесла остготским командирам такое количество ущерба и поражений (ликвидировав физически большинство участников первых заговоров), что её устранение стало целью родовой мести у многих знатных соплеменников. Да и сын Амаласунты Аталарих, если верить раннему Прокопию, не подавал никаких надежд... Он вел беспутный образ жизни, пьянствовал, в результате чего скончался 2 октября 534 года36.

Когда Аталарих умер, Амаласунта впала в отчаяние и длительный шок. Её личная трагедия и безнадёжное политическое положение вынудили искать расположения военной знати. Процитируем хрониста Иордана: «Тогда мать Аталариха, для того чтобы готы не пренебрегали ею из-за слабости ее пола, обдумав все это, объявила ради родства королем своего двоюродного брата Теодата, вызвав его из Тусции, где он жил как частное лицо около своих лавров» 37.

Очевидно, что назначение Теодата (Теодахада) соправителем Амаласунты было утверждено Юстинианом. Иначе и быть не могло в условиях юридической зависимости остготской политической структуры от официального Константинополя. Ещё перед смертью Аталариха, в Италию прибыло византийское посольство под руководством сенатора Александра. Оно, как считает Прокопий, подтвердило готовность Юстиниана помочь Амаласунте в случае попытки оппозиции устроить переворот. Также посольство Александра гарантировало признание Амаласунты королевой со стороны Нового Рима. Она официально получила королевский титул и заверения $b$ абсолютной поддержке от императора Юстиниана ${ }^{38}$. Дополнительно Александр привез распоряжения императора о выдаче африканских дезертиров и наказании остготских пиратов.

В связи с вышеизложенным, масштабно растиражированное историками высказывание летописца Прокопия, что Амаласунта «якобы согласилась отдать во власть Юстиниану всю Италию» 39 , можно интерпретировать

\footnotetext{
36 Procop. BG., I.3.10-11.

37 Iord. Rom., 367 et Iord. Get., 305.

38 Procop. BG., I.3.14-15.

39 Удальцова 3. В. Там же. - с. 247. Первоисточник: Procop. BG., I.3.28.
} 
совершенно в ином смысле. Скорее всего, Амаласунта торжественно подтвердила, что Италия является вечным владением и фискальной базой восточноримского императора. Ведь юридически так оно и было! Позволим себе также считать, что кандидатура Теодата в соправители (в случае ожидаемой смерти Аталариха, тяжело больного в момент прибытия посольской миссии из Константинополя) представлялась Амаласунтой императору через посредство сенатора Александра 40 .

О прямом указании Юстиниана поддержать кандидатуру Теодата, свидетельствует единогласное голосование Римского сената в поддержку реформы. О многом говорит тот факт, что после визита константинопольского сенатора Александра, Амаласунта решила избрать именно этот орган для юридического провозглашения Теодата королем. Таким образом, утверждение третьего короля остготской Италии (после Теодориха и Аталариха) осуществил Римский сенат!

Парадоксальный, на первый взгляд, факт кажется вовсе не таким парадоксальным, если проанализировать существующие исторические источники. Тщательно изучая хроники современников, внимательный читатель увидит следующую административно-династическую систему назначения верховных правителей остготского племени:

1) В 488 г. римский патриций, консул и магистр милитум Восточной Римской империи Теодорих из рода Амалов получил от императора Зенона Исавра (476-491) пост «наместника Италии».

2) В 493 г. император Анастасий I (491-518) подтвердил посольству Теодориха указ Зенона Исавра о назначении его «наместником Италии», а также даровал Теодориху множество различных административных и налоговых привилегий.

3) В 527 г. император Юстин I (518-527), в связи со смертью Теодориха, назначил на пост «наместника Италии» его внука Аталариха, в то время как «регентом наместника» должна была оставаться Амаласунта вплоть до достижения Аталарихом совершеннолетнего возраста.

4) В 534 г. император Юстиниан Великий (527-565), в связи со смертью Аталариха, объявил об одновременном назначении «наместниками Италии» двух представителей рода Амалов - Теодата и Амаласунты. При этом, Амаласунта, как родная дочь Теодориха, официально получила королевский титул и властные регалии. Привилегию утвердить Теодата на посту

40 Об этом см.: Удальцјова 3. В. Там же. - с. 247-249. 
наместника Италии и остготского короля, Юстиниан Великий де-юре передал Римскому городскому сенату.

Во всех изложенных случаях, субъектом назначения остготских королей и, соответственно, правителей Италии с прилегающими провинциями, всегда выступает персона императора Восточной Римской империи (т.е. Византии).

В самом конще 534 г. новый король Теодат (534-536) обратился с благодарственной речью к Римскому сенату. Он подчеркнул, что собирается править вместе с Амаласунтой «подобно тому как два светила изливают единый свет» 41 . Большая часть речи Теодата посвящена лести в сторону Амаласунты. Она называлась самой справедливой правительницей, достигшей уважения восточного римского императора (интересен акцент именно на персоне византийского императора - высшем моральном авторитете!). Только единодушное руководство вверенными им провинциями, говорил Теодат, может быть залогом мирной и процветающей жизни ${ }^{42}$.

Варии Кассиодора сохранили до наших дней также послание королевы Амаласунты к Римскому сенату по случаю утверждения Теодата. Королева подчеркивала, что человеку дарованы два глаза и две руки, а государству должны быть дарованы два правителя, чтобы их дуумвират обеспечивал нормальное функиионирование организма 43. Амаласунта уделила много внимания классическому образованию Теодата, без которого управление римскими провинциями, на её взгляд, представлялось невозможным.

Считалось, что Теодат много времени и внимания уделял философским занятиям 44, в то время как военная карьера никогда не была его целью. Отсутствие командирских способностей, безусловно, могло быть одним из оснований для выдвижения Теодата Амаласунтой в соправители. Вполне возможно, она надеялась сохранить власть в своих руках, продолжая создавать видимость наличия руководителя мужского пола (как уже было в случае с Аталарихом). Для того, чтобы Теодат не мешал проводить собственную политику Амаласунта даже платила ему деньгич5. Впрочем, Прокопий считает, что Теодат имел давние контакты с константинопольским дворцом и ещё в конце 533 г. предлагал Юстиниану передать под прямое управление византийских чиновников вверенный ему ещё Теодорихом регион - Тусцию.

\footnotetext{
41 Cass. Var., X.4.1-2.

42 Cass. Var., X.4.7-8.

43 Cass. Var., X.3-2.

44 Предполагаем близость короля Теодата к поздним итальянским стоикам.

45 Cass. Var., VIII.23.2.
} 
За это Теодат желал добиться сенаторского звания, богатых аграрных поместий в Малой Азии и пожизненного обеспечения со стороны константинопольского фиска ${ }^{46}$.

В любом случае, назначение Теодата спутало Амаласунте карты. Она не только чрезвычайно потратилась, возвратив ранее конфискованные в пользу равеннского дворца имения семье Теодата, но и была этой семьей обманута. Когда Амаласунта потребовала от Теодата прекратить совершать разбойничьи набеги на близлежащие поместья латиноязычных земледельцев в Тусции, то «заслужила вечную ненависть короля» 47 . Амаласунта, впрочем, попыталась повернуть ситуацию вспять и выступила перед Римским сенатом с речью о заслугах и добродетели Теодата, называя распространенные в обществе обвинения против него клеветой 48 . В обмен на публичную поддержку, королева вступила с Теодатом в тайные переговоры, требуя молитвенной клятвы в пожизненной верности и лояльности. Теодат дал такую клятву49, но тут же её нарушил. На всё это философу-стоику потребовался один месяц...

В последние дни октября 534 г., королева Амаласунта была арестована и отправлена в Тусцию, на остров Мартано (Лаго ди Больсена). Теодат, в свою очередь, заручился поддержкой многочисленных родственников ликвидированных властью Амаласунты военачальников 50 . О том, что случилось далее, рассказывает хронист Иордан: «Теодат, забы о родстве, спустя некоторое время удалил королеву из равеннского двориа и отправил в изгнание на остров, расположенный на Вольсиненском озере. Там, прожив в печали немного дней, она была задушена $b$ бане его приспешниками» 51.

Итак, жизненный путь Амаласунты оборвался весьма печально. Её предал родственник из дома Амалов, который сам занял королевское место. Муж Амаласунты, консул Евтарих, умер на заре их совместной жизни (в 522 г.), а единственный сын Аталарих был изъят из дома в пользу остготских военачальников, в кругу которых пристрастился к вину и умер, не успев даже приступить к реальному выполнению административных обязанностей. Вместе с этой личной драмой, период правления Амаласунты - время настоящего расцвета культуры на Апеннинском полуострове. Италия достигла

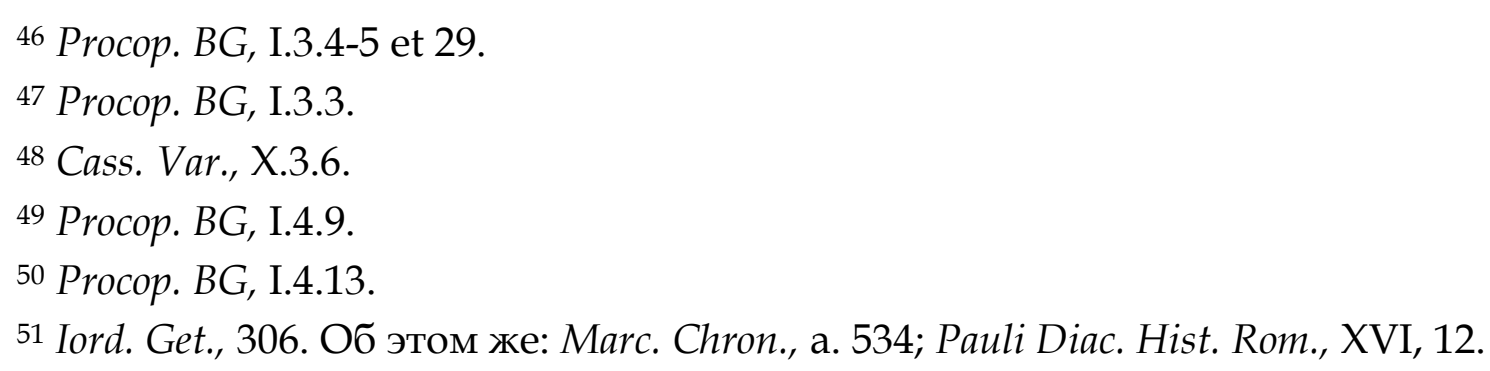


пика культурного и политического ренессанса при Теодорихе Великом и уверенно сохраняла это положение при регентстве Амаласунты.

Амаласунта правила восемь лет, как регент Аталариха (526-534 гг.) и всего полгода юридически являлась королевой (2 октября 534 - 30 апреля 535 гг.). Амаласунта проводила неоднократные переговоры с представителями императора Юстиниана и, по всей видимости, была ценным чиновником на службе Восточной Римской империи. Она давала клятвенные заверения в лояльности Константинополю и, заметим, не существовало более удачного способа продемонстрировать своё подчинение императору, кроме как принять и расположить его флот и армию на территории остготской Сицилии (перед вступлением Велизария в Северную Африку). Вот почему смерть Амаласунты стала большой проблемой для императора Юстиниана. Власть в Италии несанкционированно захватил Теодат - человек до крайней степени ненадежный.

Убийством назначенной Константинополем наместницы Амаласунты Теодат оскорбил императора и предал интересы Восточной Римской империи. Уже на следующий после убийства день, 1 мая 535 года началась война. Де-юре, дальнейшие боевые действия византийской армии против остготов являлись разгромом «итальянского мятежа». Однако, де-факто, со смертью Амаласунты началась самая кровопролитная война VI века - противостояние между императором и варварским миром, длившееся двадцать лет (535-555 гг.) и приведшее к победе Юстиниана Великого и временному 52 восстановлению полноценного контроля Византии на землях Италии, Южной Галлии, Паннонии и даже юго-восточной Испании.

PhD in Political Science Viktor Melnyk (Kyiv, Ukraine)

The Governance of the Queen Amalasuintha in Italy (526-535 AD): Description from the View of the Legal History

The legal history of the first half of the 6th century AD is characterized by the revival of the legal power of the Roman Empire, represented by officials of the New Rome (Constantinople). De jure, the Eastern Roman Empire (Byzantium) remained the rightful heir to the political, administrative-territorial, public property law of Imperial Rome. In addition, most citizens of the Western part of the Roman Empire, created according to the Edict of Emperor Theodosius (395 AD), despite the actual occupation by the barbarian tribes, continued to believe in the power and power of

\footnotetext{
52 До начала 570-х гг.
} 
the only Roman emperor - the emperor of Byzantium. Barbarian leaders understood the need for support from the people. Therefore, the kings of the Ostrogoths, Visigoths, Vandals, Burgundians, Suevs etc took their titles and signs of royal power as a formal gift from the emperor of the Eastern Roman Empire. Among the barbarian kings of the early Middle Ages, the Ostrogoth Amal dynasty stands out. In this article, the subject of the study was the royal power of the first legally fullfledged female ruler of Italy, Amalasuintha.

Key words: Queen Amalasuintha, Amal Dynasty, Ostrogothic Italy, Barbarian Kingdoms, Early Middle Ages, Law of Power, Imperial Will, Edictum Athalarici, Senate of Rome, Position of the Governor of Italy.

Кандидат политических наук Виктор Мельник (Киев, Украина)

\section{Правление королевы Амаласунты в Италии (526-535 гг.): историко- юридическая характеристика}

Юридическая история первой половины VI века н. э. характеризуется возрождением юридической мощи Римской империи, презентованной чиновниками официального Нового Рима (Константинополя). Де-юре, Восточная Римская империя (Византия) оставалась полноправным наследником политических, административно-территориальных, публичных имущественных прав Императорского Рима периода домината. Кроме того, большинство граждан Западной части Римской империи, созданной согласно Эдикту императора Феодосия (395 год н. э.), несмотря на фактическую оккупацию их территорий, осуществленную варварскими племенами, продолжали верить в силу и мощь власти единственного на свете римского императора - императора Византии. Варварские вожди также понимали необходимость поддержки со стороны преимущественно латиноязычного и «римско-мыслящего» народа. Именно поэтому короли остготов, вестготов, вандалов, бургундов, свевов и т. д. всегда принимали собственные титулы, регалии и знаки королевской власти в качестве формального подарка от императора Восточной Римской империи или же в качестве подтверждающей императорской грамоты. Среди варварских королей раннего средневековья особо выделяется остготская династия Амалов. Нашим предметом исследования стала королевская власть первой полноправной, с юридической точки зрения, женщины-правительницы Италии - Амаласунты (годы жизни: 495-535).

Ключевые слова: королева Амаласунта, династия Амалов, остготская Италия, варварские королевства, раннее средневековье, право силы, императорская воля, Эдикт Аталариха, Сенат Рима, должность наместника Италии. 
Кандидат політичних наук Віктор Мельник (Київ, Україна)

Правління королеви Амаласунти в Італії (526-535 рр.): історико-юридична характеристика

Юридична історія першої половини VI століття н. е. характеризується відродженням юридичної сили Римської імперії, репрезентованої чиновниками офіційного Нового Риму (Константинополя). Де-юре, Східна Римська імперія (Візантія) залишалася повноправним спадкоємцем політичних, адміністративно-територіальних, публічних майнових прав Імператорського Риму доби домінату. Крім того, більшість громадян Західної частини Римської імперії, створеної відповідно до Едикту імператора Феодосія (395р.), незважаючи на фактичну окупацію їхніх територій, здійснену варварськими племенами, продовжували вірити в силу та міць влади єдиного на світі римського імператора - імператора Візантії. Варварські вожді також розуміли необхідність підтримки 3 боку переважно латиномовного та «мислячого по-римськи» народу. Саме тому королі («рекси») остготів, вестготів, вандалів, бургундів, свевів тощоі завжди «отримували» власні титули, регалії і знаки королівської влади в якості формального подарунка від імператора Східної Римської імперії або ж в якості підтверджуючої імператорської грамоти. Серед варварських королів раннього середньовіччя особливо виділяється остготська династія Амалів. Нашим предметом дослідження стала королівська влада першої повноправної, з юридичної точки зору, жінки-правительки Італії - Амаласунти (роки життя: 495-535).

Ключові слова: королева Амаласунта, династія Амалів, Остготська Італія, варварські королівства, ранне середньовіччя, право сили, імператорська воля, Едикт Аталаріха, Сенат Риму, посада намісника Італії.

* Мельник Виктор Мирославович - кандидат политических наук, ассистент кафедры политологии философского факультета Киевского национального университета имени Тараса Шевченко, преподаватель кафедры философии и общественных наук Винницкого национального медицинского университета им. Н. И. Пирогова, главный редактор научного журнала «Анналы юридической истории», член Американского общества юридической истории. E-mail: melnyk1996ethnology@gmail.com. 